\title{
Individualization Strategies Among City Dwellers in Contemporary Africa: Balancing the Shortcomings of Community Solidarity and the Individualism of the Struggle for Survival
}

\section{Alain Marie}

In urban Africa today, like elsewhere, the purported survival strategies of individuals are determined constantly by severe material constraints. The poor and the new poor are overwhelmingly new city dwellers dependent on precarious, intermittent odd jobs (petits boulots); ${ }^{\mathrm{I}}$ single women with small children; young school dropouts (déscolarisés), condemned to the expediencies of the streets, illicit actions and, in many cases, delinquency; unemployed graduates (diplomés-chômeurs), without opportunities for paid employment; as well as those designated successively in the vernacular as conjoncturés, déflatés and compressés (i.e. workers affected by wage reductions, permanent employees downgraded to temporary contracts or casual labour, and workers who have lost their jobs through massive redundancies). These individuals can meet only the most basic needs (eating, feeding their children, paying the rent). When survival becomes an issue, long-term strategies tend to be constrained by the need to fulfil the most basic needs and daily necessities. At any rate, pursuit of this objective does not involve selective mobilization of optimized means, when those who admittedly are looking out for themselves (se cherchent), rummage about (grouillent à droite [et] à gauche), pursue small jobs in unskilled manual labour or portering, or as night watchmen (racolage pour trouver des petits contrats de manoeuvrage, de manutention ou de veilleur de nuit), ${ }^{2}$ search constantly for opportunities to sell items that they bought for a little bit less, inland or across the border. They may also try to establish a business or small craft shop and, during the interim, get by with difficulty thanks to sporadic aid from relatives who are also unemployed. All rely on circumstances, encounters, the economic situation, luck and what they call fortune (la chance). Except for some graduates and former wage employees (some of whom have cultural and social capital), they very rarely have the relative latitude of a choice of means and ends justifying what we might call strategies, which are often

I. The expressions in italics are from the French African vernacular in the major cities of West Africa.

2. These activities are occasional, irregular, temporary, isolated and very poorly paid jobs. The trick is to discover them by expanding one's network and increasing the interactions, offers and applications. 
merely grass-roots activism and efforts to reach out in all directions. While they certainly seem very busy, their activities do not offer genuine prospects or opportunities to pursue coherent ambition.

These survival strategies are indeed rigidly defined by poverty (the common feature of want - manque de moyens - in conjunction with the obsessive "there is no money" - y a pas l'argent) and consequently by the informal economy and illicit activities, amid scarcity and anomic laissez-faire that both imposes and promotes individualism as imperative in the struggle for survival. Nevertheless, all these means of survival are embedded in a social and cultural setting marked by anti-individualist community traditions that clearly attribute a specific style and significance. In this respect, they always seem associated with a strategy. On the one hand, individualism is prescribed by economic need and is based on the universal inclination to impose one's own interests (of which Africans have as many as anybody else). On the other hand, the solidarity ethic derives from longstanding cultural traditions that are deeply internalized, but are also sustained by requests for help that are more urgent than ever in this crisis. Between these two contradictory forms of logic, individuals therefore need to practise well-informed strategies of compromise. Noting the shortcomings of community solidarity and the worsening threats of witchcraft sanctioning these shortcomings, they resort to avoidance, protection and greater individual autonomy involving extracommunity religious and political involvement.

Though their economic survival methods are often far from strategic or original, they resort to existential and social survival strategies. Their conduct comes to reflect a specific world state, implicitly and often explicitly involving transformation of both the person and of the ways that the overall being and they themselves pursue this objective, from reinterpreted traditions and reclaimed modernity, a specific combination of means.

Analysis of this complex and often ambivalent process will benefit from relating the social and cultural logic to the basis of community solidarity. After this anthropological digression, the microsociology of concrete situations and the meanings attributed by the city dwellers facilitate highlighting this explicit and reasoned strategic dimension of their social conduct.

\section{ANTHROPOLOGICAL FOUNDATIONS OF COMMUNITY SOLIDARITY}

First of all, a classical empirical observation comes to mind. In traditional African societies, most of the different forms of social milieux (consisting of family relationships, or links among neighbours based upon production, reciprocal consumption, or political-territorial records) are interwoven so well that all social relationships are constantly imbued with affects, that the 
distinction between the public and the private spheres is hardly relevant, and that solidarity appears as an a priori, ontological and axiological principle, largely out of range of analytical and critical considerations. ${ }^{3}$

Anthropological tradition has long settled for a cultural-functionalist perspective focusing on the virtuous specificity of community solidarity - as opposed to the individualism of Western modernity - that directly integrates individuals in groups and turns people into their own recourse (Ouolof adage). ${ }^{4}$ The group's primacy with respect to the individual is thus manifested by the absence of the household concept (of a conjugal family) which is not recognized as a specific category in the language. Nor is it acknowledged as an independent entity in practice: the individual is relevant only in collectives of inclusive parentage (the extended family, the lineage, the clan).

\section{Solidarity as the embodiment of the realism of mutual assurance}

Nonetheless, a less culturalist perspective, based on the simple idea that societies sanctified the basis of their operations and reproduction, reveals that solidarity's importance derives primarily from the objective need for reciprocity over the short and long term.

Simultaneously, there is a daily need for ordinary cooperation to cover risks and provide protection from life's dangers. ${ }^{5}$ Diachronously (over the course of seasons, years and generations), the reciprocity principle underlies loan and restitution cycles. ${ }^{6}$ While awaiting the upcoming production, the collectivity consumes the preceding production under the supervision of the eldest, who run the annual system of services and redistributions. Over time, the ascendant generations sustain the descendant ones, which, after receiving these advances, provide compensation in the form of aid and services when they in turn enter the production cycle and later become responsible for supporting the generation of grandparents, when the birth of grandchildren starts a new cycle.

From this materialist perspective, the community henceforth appears as

3. A detailed description of the implicit and explicit socialization procedures that give rise to individual habits driven by a natural inclination toward solidarity appears in the study by Jacqueline Rabain, L'enfant du lignage. Du seurage à la classe d'âge (Paris, 1979), on informal education among the Ouolof in Dakar.

4. This tradition remains significant in Louis Dumont, Essais sur l'individualisme. Une perspective anthropologique sur lidéologie moderne (Paris, 1983).

5. Greater mobilization of the workforce for tasks exceeding the capacities of domestic units; gifts of food, various services and prized commodities that sustain support networks and offer entitlement to various gifts in return to cope with daily needs, such as social obligations or production hazards; recurring gestures of hospitality and commensality; reciprocal participation in wedding or funeral expenses; sets of services to the eldest and the chiefs in return for guaranteed return disbursements on their part, etc.

6. Cf. Claude Meillassoux, Femmes, greniers et capitaux (Paris, 1975). 
a mutual organization based on the reciprocity principle. Far from being considered original, this principle is to be interpreted as the modality of an objective need for protection from the insecurity of the present and insurance covering future uncertainties and economic and human resources wherever the material circumstances compel an immediate mutual management of resources.

The question nevertheless arises as to how this reciprocity is actually protected from any shortcoming by three forms of social logic operating in a context of necessary circular involvement: the debt logic, the hierarchical logic and the anti-individualist logic.

\section{The realistic gift: the debt logic}

The debt logic underlies the relationship between a donor (who takes charge as the creditor) and a donee (who is subordinate as the debtor and is obliged to repay the debt incurred sooner or later). This practice legitimizes his permanent right to receive mutual aid and cooperation and, more generally, to support (or accumulate) social capital: such relations are so much more useful that they are vital.

This perspective places the act of giving in a more realistic light. According to Mauss's formula do ut des (I give so that you will give): ${ }^{7}$ if an initial gift inspires a return gift, it is basically an investment to be recovered in the long run. Giving means taking out insurance on the near or distant future. Such insurance is secured by the law of reciprocity (i.e. personal interest in honouring one's debt to safeguard one's place in the cycle of reciprocal exchanges), and everything passes before the tribunal of public opinion (which is quick to impose sanctions on unscrupulous or insolvent debtors). ${ }^{8}$ This debt logic, however, exists continuously in African societies.

The debt logic is first of all the ontological and metaphysical debt of mortals with respect to Gods, civilizing heroes, ancestors, preceding generations, and those who died recently. It underlies everything (customs, knowhow, territorial prerogatives) and is a condition for everything (health, fecundity, fertility). Individuals also have an existential debt toward their social surroundings: a person's ontosociological debt (always/already in debt) toward the parents who transmit life, enter within a lineage, attribute status and identity, raise, educate, organize the rites of magic protection and initiation and later arrange a marriage marking the transition to adulthood; a husband's debt toward his in-laws who have given the wife ensuring his offspring, who are the ultimate insurance for old age and survival (this

7. Marcel Mauss, “Essai sur le don”, in Marcel Mauss (ed.), Sociologie et anthropologie (Paris, 1960).

8. For a critique of the culturalist orientation of Maussian theory, from a materialistic point of view, cf. Alain Marie, "L'échange: sous le don, la dette", Sciences humaines, 23 (1998), pp. 28-31. 
progeny is responsible for caring for elderly parents before giving them honourable funerals that are the key to a peaceful life after death); ${ }^{9}$ the debt of ordinary people to their chief and the eldest in the lineage, who, because they are at the heart of a system of tributary or ritual services, accumulate wealth for redistribution as aid in case of need and as ceremonial spending (intended to honour the ancestors and divinities, on whom the living depend for their wellbeing).

The debt logic thus perpetuates such a close network between creditors and debtors that a debtor's balance with one individual may be offset by a creditor's balance with a third party. Any debtor, upon becoming economically independent, is in turn responsible for helping others incur debts, both because of his social obligations and his world view and because of his personal interest (upward social mobility, insurance for the future).

\section{The hierarchical principle}

In return, this socially pre-established harmony between the debt's social logic, individual rationality of running into debt, and personal desire for acknowledgement presumes and implies intrinsically hierarchical relationships between the members of the community. Disregarding exchanges of equivalent services ${ }^{10}$ - which impose no obligation other than that of the giver, giving for rather short terms - debt relations, however, are unequal. Whether as accompanying ${ }^{\mathrm{II}}$ or constituent factors, ${ }^{\mathrm{I2}}$ they always affirm a relationship between the dominant and the dominated party.

\section{Anti-individualism: witchcraft and its effectiveness}

The beliefs concerning witchcraft that prevail among different African societies somehow complete this consubstantial liaison between debt logic and hierarchical logic. Understanding their deep-seated rationality will elucidate their hidden functionality.

If these beliefs make sense to the social agents invoking them to explain the various misfortunes attributed to the evil and occult actions of witches around them, they are not as senseless as they might appear. Regarding

9. This is why among the Dan from Ivory Coast, for example, regardless of the amount of matrimonial compensation initially paid for the wife, the husband's debt toward his in-laws is infinite: it is said that "the dowry never ends", in that the husband has a never ending obligation to give gifts, to accommodate, and to help his in-laws (personal observation).

10. E.g. land clearing and work in the fields of others, joining collective hunts, mutual aid in house building, reciprocal guarding of part of the herds.

II. The relation between parents and children, between older and younger generations, between chiefs and subjects.

12. The relation between givers of a wife and recipients, between patron and client, between protector and protégé, between benefactor and beneficiary. 
Durkheim's formula about the religious sphere, ${ }^{13}$ if they seem like a delirium, as soon as this delirium becomes collective, it must be based on solid foundations. It should relate (symbolically and therefore indirectly) to reality (objective) and should have a realistic significance (expression or revelation of some of its properties). Without going into detail, we will recall the main assertions. ${ }^{14}$

(I) Mankind's unhappiness is caused largely by other people, who; endowed with magic occult and evil powers, are responsible for most misfortunes, of which the accumulation or repetition reveals that they arise from malicious intentions. According to the theory of witchcraft, certain individuals are responsible for, and are therefore guilty of, misfortunes that afflict those around them. ${ }^{15}$ This position relieves society of all blame. ${ }^{16}$

(2) Witchcraft is all the more effective and malicious, because it pitches people against those around them, parents, husbands and wives, spouses in polygamous unions and their respective children, matrimonial alliances, neighbours (nowadays schoolfellows, colleagues or competitors). Within their social circle, all people therefore find both those who are inclined to help them and others who turn out to be their worst enemies. Thus, like any rather cohesive environment, but with a more intense role as the site of daily life and a "unit of survival" ${ }^{17}$ communities are presented as essentially ambivalent, very remote from all Western fantasies of being harmonious and equipped to weather any serious internal conflict.

(3) This community ambivalence arises from ambivalence among people. Witchcraft is not the attribute of certain predesignated categories of individuals. Anybody can become a witch or sorcerer: by heredity, by particular circumstances of conception or birth; by accidental contamination; by a magic spell; by deliberately joining a secret fraternity of sorcerers; or quite simply because the distinction between common empirical reality and the surreality of the ruling occult powers is fluid. A vast clandestine and mysteri-

13. Emile Durkheim, Les formes élémentaires de la vie religieuse (Paris, 1912).

14. A more detailed analysis appears in Alain Marie, "Du sujet communautaire au sujet individuel. ne lecture anthropologique de la réalité africaine contemporaine”, in Alain Marie (ed.) L'Afrique des individus. Itinéraires citadins dans la société contemporaine (Abidjan, Bamako, Dakar, Nyamey) (Paris, 1997), pp. 53-IIO.

I5. Business failures, poor harvests, accidents, deaths of young children, infertility, impotence, stillborn babies, successive illnesses, decline, madness, epidemics, death in the family, death of the victim etc.; in today's world, also traffic accidents, losing one's job, dropping out of school, bankruptcy, etc.

16. Ideas about witchcraft help exonerate society from any semblance of a cause for criticism or subversion (in addition to sanctifying the social order in the stories of the world's creation by the gods and the divine heroes and society's establishment by our forebears). The community order is thus sanctified according to Durkheim's definition of the term: the profane shall not affect it; individuals have no alternative but to submit. For an analysis related to this perspective, $\mathrm{cf}$. Max Gluckman, "Crises morales et solutions magiques", Economies et sociétés, Cahiers de l'I.S.E.A., 2 February 1967, pp. 5-48.

17. Norbert Elias, La société des individus (Paris, 1991, fourth French edition). 
ous underworld of antisocial sentiments and aggressive impulses can submerge anybody at any time, and unknowingly even force them to the other side of the spectrum of community sociability, into the invisible and formidable mirror world, where sorcerers interact, take up with each other, sometimes get into confrontations and always feed on each other's misfortunes. Every human being has the potential to become a sorcerer.

(4) Surely, this means that the sorcerer is the individual himself as envisaged in his most intimate dimension, the most individualized, least socialized and even most resistant to all socialization undertaken: hidden, often subconscious, affects and secret, often unknowing, impulses. The different dispositions attributed to the sorcerers depending on the cases correspond with an all-encompassing characterology. It provides a framework for identifying abuses of power or successes of eminent individuals, ${ }^{18}$ that are sometimes too overwhelming or too quick for comfort, and for stigmatizing ordinary people who may be suspected of using sorcery to indulge in vengeance, jealousy, envy or unbridled ambition, or refusing to remain in their social station.

Through these representations, community societies thus stigmatize individualism as a threat, while acknowledging implicitly that it is a universal potentiality and temptation. In this respect, these societies are quite antiindividualist.

(5) From this perspective, sorcerers are optimally suited by virtue of their individualism to challenge the debt logic and the hierarchical principle. Magically controlling those around them, ${ }^{\text {I9 }}$ feeding on their vital strength to reinforce their own, offering some of those close to them as sacrificial meat at cannibalistic feasts of their brotherhood, sorcerers are just the people to violate the debt law. As creditors fearing neither God nor man, they take without giving, accumulate without returning, exploit, steal, pillage, and kill, assume no obligation but take everything. Simultaneously, they subvert the hierarchical principle: as men of power, they use it arbitrarily (they always want more and use it for their own benefit without redistributing); as common people, they rebel against their situation, are devoured by jealousy or by ambition, attack things and people and sometimes even become serial killers. ${ }^{20}$

I8. Chiefs, distinguished individuals, exorcists, religious officials, great warriors, political entrepreneurs, rich merchants; in today's world, political officials, successful businessmen, outstanding pupils or students etc.

19. For example by making their "invisible" doubles work as slaves on their "invisible" plantations. 20. This account presumes a view of the social world as a "closed society" devoted to simple reproduction, excluding expanded reproduction that indefinitely increases the resources and diversifies the positions to be conquered. In a closed society, individualism therefore automatically has a detrimental effect on others. Generally, a "materialist" explanation prevails for this symbolic representation. Following a case study on witchcraft in France today, Jeanne Favret-Saada noted that faith presumed a closed conception of the social universe and its economic resources: each individual is in charge of a domain; once all domains have been appropriated, sorcerers need to 
(6) Beliefs in witchcraft thus concern power as well, ${ }^{21}$ in that all temporal power and all extraordinary abilities are considered based on the surreal local divinities, genies, ancestors - as well as on the magic gatherings. Chiefs (the political leaders in modern contexts), exorcists with supernatural powers, dignitaries, clan elders, and the elderly in general, are believed to wield magic powers of defence and aggression, enabling them to protect themselves and their dependants from attacks by jealous sorcerers, and to inflict punishment as defenders of the established order, on those guilty of individualism that threatens the community law. They are the ones most likely to organize or control the rituals for detecting and neutralizing sorcerers. ${ }^{22}$ Moreover, by implementing the universal scapegoat mechanism, the beliefs concerning witchcraft are intrinsically conducive to maintaining the community order. People understand that they can always resort to witchcraft (even unknowingly) and are aware of what happens to those labelled as sorcerers after a trial or simply by rumour. ${ }^{23}$ Especially among the common people known as "simple" (as the people without magic powers are known in Ivory Coast), everybody, therefore, tries to suppress all evil (i.e. individualist) ideas, and ostensibly to manifest conviviality and benevolence (i.e. altruism) toward others.

(7) The individualist temptation, however, remains omnipresent (nobody escapes), as the witchcraft theory implicitly acknowledges, and as several ethnographic observations noting the frequent recurrence in community society of suspicions of witchcraft and, sometimes, legal-therapeutic rituals following an accumulation of misfortunes. Overall, indigenous socioanthropology supports, metaphorically, the powerful belief in the indomitable duality of society and the individual: society and mankind are equally ambivalent in that both harbour disturbing and threatening twilight zones beneath their ordinary, reassuring and convivial surfaces. ${ }^{24}$

Far from weakening individualist tendencies, however, the postcolonial

remove resources magically from other domains to expand their own. See Jeanne Favret-Saada, Les mots, la mort, les sorts. La sorcellerie dans le Bocage (Paris, 1979).

21. On political aspects of witchcraft in societies based on lineage, see Marc Augé, Théorie des pouvoirs et idéologie (Paris, 1975), and idem, Pouvoirs de vie, pouvoirs de mort (Paris, 1977). Regarding the phenomenon's context with respect to "modern" political stakes in contemporary Africa, see Peter Geschiere, Sorcellerie et politique en Afrique. La viande des autres (Paris, 1995).

22. For an especially demonstrative case study, see Pierre Bonnafé, Nzo Lipfu, le lignage de la mort. La sorcellerie, ideologie de la lutte sociale sur le plateau Kukuya (Nanterte, 1979).

23. Rumour itself is fraught with danger: it activates the magic forces of powerful men and exorcists.

24. Representations depict persons as consisting of several psychological components: a vital force, defensive and aggressive powers, shadow, mirror images. Thus, the idea of the individual's essential duplicity appears rational ("I am another" and even several others). We understand why an individual accused of witchcraft accepts this accusation: he knows that his double may have acted maliciously and beyond any conscious control of his, and that it is very believable if his double has been captured or manipulated without his knowledge by a sorcerer's double. See La notion de personne en Afrique noire, Colloques du CNRS (Paris, 1973). 
regimes have assumed responsibility for this community regime - based on plans for debts, hierarchy and anti-individualism - by operating a type of conservative modernization entailing supercommunitarization of global society through political domination based essentially on clientelism (i.e. the extension of the debt to the macrosociological scale).

\section{MODERNITY: SUPERCOMMUNITARIZATION AND SOCIOPOLITICAL DEBT}

Establishing itself as the exclusive agent in building the nation, as the eminent owner of the collective wealth, and as the principal actor for development, the postcolonial state inevitably became the privileged instrument and main site of the accumulation of wealth and extortion implemented with impunity by a kleptocratic oligarchy, obtained primarily through tributary withholdings on the export revenues, customs receipts, and foreign aid.

This politique du ventre (gut politics) ${ }^{25}$ also works according to the debt logic: acceding to the prebend positions requires an invitation either from the prince or his entourage, support from a political sponsor, a network of friends in high places, or appointment as a leader by a sufficient number of people willing to stake their careers on somebody they expect to become their protector. The oligarchy also comprises several clientelist networks with which the members are associated, as well as the relations of creditors to debtors and mutual complicity, while remaining linked to those who enabled their rise from below and expect support, aid, intervention, and financial generosity from them.

In fact, these acts of redistribution provide protection from jealousy and possible vengeance by the surrounding community, who are inclined to perform the most scrutinizing evaluation of the services rendered by the one who has succeeded, finding him ungrateful if he seems to forget everything that his relatives (of the clan, the lineage, the village) have done for him, and mobilizing the power weapons of aggression (maledictions, misfortunes, attacks through witchcraft) to remind him that individualists risk all kinds of sanctions (bad luck, disaffection by a superior, accident, family misfortunes, loss of employment, illnesses, death), intended to reimpose the community value system on those inclined to abandon it or to punish them if they continue along this course.

Nonetheless, an urban middle class (professionals, teachers, university and secondary school students, subalterns, junior managers, permanent employees and workers, businessmen and small entrepreneurs) wield considerable force with respect to politicians. In economic crises accompanied by austerity measures, they form social movements that are a much greater threat to politicians because they are joined by the lower classes from the

25. Jean-François Bayart, L'Etat en Afrique. La politique du ventre (Paris, 1989). 
cities (especially by the young people without jobs and those existing on the margins of society).

The postcolonial state has long averted this threat through a clientelist redistribution to the different components of this middle class. This has also given rise to a very pivotal role between state and society: therefore, directly or indirectly, part of the state manna is redistributed among the working classes. All modern city dwellers have an obligation to share their advantages with their less fortunate relatives in the towns and the villages. They must be hospitable toward visitors, provide lodgings to newcomers in search of jobs in the city, take responsibility for a schoolchild of relatives, contribute toward health expenses, build homes for older generations remaining behind in the village, contribute toward ceremonial expenses (funerals, weddings, baptisms), pay dues to associations modernizing the village, donate money at the request of a member of the community or to support a relative in need, speak to a relation with connections regarding a request for employment or an administrative procedure etc.

The redistribution of solidarity, however, derives from this debt logic that underlies community sociality. Everybody knows all that they owe from birth to their creditors, and depend on them. Likewise, everybody knows when lack of respect (shortcomings toward the different guarantors of the community hierarchy), and lack of acknowledgement (literally the individualist attitude of whoever fails to "acknowledge" his debts) will incur heavy penalties. On the one hand, in case of adversity, a person would no longer be able to count on others, and would forfeit the right to collect from his own debtors. ${ }^{26}$ On the other hand, he would immediately risk punishment by malediction, misfortune or attacks by witchcraft. ${ }^{27}$

Upon taking stock of this group of causalities, both objective and subjective, real and imaginary, sociocultural and sociopsychological, cognitive and affective, sociological and religious, ${ }^{28}$ the hold on citizens of community structures (i.e. extended families, lineage networks, gatherings of people from the same village or region, ethnic associations) may be interpreted as if they pertain simultaneously to specifically associative and urban-style

26. Reciprocity is intrinsically an extremely rigorous and effective constraint: if an individual abstains from attending large funeral gatherings, he risks being left alone to bury his loved ones in shame and, worse still, being buried all alone himself "like a dog". He will be doomed to wander eternally and to oblivion, which is tantamount to hell.

27. This explains the sudden changes of fortune, the accidents, the diseases, death of a loved one, loss of a job, disaffection of one's patronage, professional failure, and persistent failures on examinations or recruitment tests. The suddenness, accumulation, or repetition of all such events reveals that they are far from fortuitous.

28. Though analytically distinct, they are in reality united in "a wealth of imaginary social meanings" that stick together and form a bond between the social actors, who think in their world and act strategically within it without needing to disassociate the one from the other. See Cornelius Castoriadis, L'institution imaginaire de la société (Paris, 1975). 
structures, even if they increase in number, moreover, as they become more integrated in urban society. ${ }^{29}$

\section{INDIVIDUALIZATION STRATEGIES AS A MEANS OF ADJUSTING AND RECONSIDERING SOLIDARITY}

Benefiting from the services of this mutuality, based on the community of origin, clearly requires ongoing participation in the underlying reciprocities and honouring one's debts, while in turn placing others in one's debt. Amid this endemic economic crisis exacerbated through neoliberal structural adjustment plans, the stories of African city dwellers today reveal that the renowned community solidarity is needed more than ever but is also increasingly a source of dissatisfaction. ${ }^{30}$ This contradiction conveys all previously concealed ambivalence: the benefits of mutual aid and gifts without apparent interest harbour a utilitarian logic of social standing; the apparently spontaneous inclination to sacrifice for the sake of solidarity embodies constraints of debt and the terrorist arsenal of anti-individualist repression guaranteed by witchcraft.

\section{Dysfunctional aspects of solidarity: individualization among city dwellers}

"You Europeans are different from us Africans: you feel solidarity!" The preceding analyses obviously substantiate this paradoxical statement by a young unemployed citizen of Abidjan. This assertion appears to reverse the generally recognized stereotypes. Understanding that the man was not referring to the same type of solidarity resolves the paradox.

On the one hand, he was emphasizing to what extent, given their absence in his society, our minimum wage and our different types of insurance (unemployment, sickness, old age etc.) express genuine macrosocial solidarity in European society (which implicitly raises questions as to whether our private individualism is the counterpoint to general conditions providing anonymous guarantees against risks, thereby rendering solidarity with the surrounding community unnecessary).

On the other hand, like many other speakers, ${ }^{31}$ the young man also notes

29. These are ad hoc gatherings based on free individual accessions and released from the community framework: mutual aid and mutual savings groups - tontines - between neighbours and colleagues; sports associations, recreational groups, committees of parents of schoolchildren, neighbourhood associations, self-defence groups against crime, syndicates, political parties, churches, prayer groups, fundamentalist Islamic communities etc.

30. See Alain Marie, "Y a pas l'argent': l'endetté insolvable et le créancier floué, deux figures complémentaires de la pauvreté abidjanaise", Revue Tiers-Monde, 36 (1995), no. 142, pp. 303-324. 31. Statements recorded in Abidjan between 1992 and 1997 in several working-class neighbourhoods. See François Leimdorfer and Alain Marie (eds), Individualisations citadines et développement d'une societte civile: Abidjan et Dakar, Research report commissioned by the ministry's representative for cooperation and French language, I.E.D.E.S. (Université de Paris I), June 1998; Alain Marie (ed.), Paradoxes de l'individualisation dans la société abidjaaise. Etudes de cas en milieu social 
that amid the hardships of the economic crisis (which has been largely endemic since the late 1970s) and structural adjustment plans, community solidarity has been found wanting. From becoming conjoncturés and subsequently déflatés and compressés, the middle classes of Abidjan are no longer able to serve as much and as consistently as before as liaisons between the state's clientelism and the working-class circles, or to redistribute to the surrounding community. Wage freezes followed by pay cuts, diminishing revenues from independent activities, ${ }^{32}$ insecure company jobs, ${ }^{33}$ early retirement, abrupt redundancies without compensation, unemployment of several graduates condemned to the expediencies of the informal economy, unpaid traineeships, and reliance on relatives, the dissemination of survival activities among young people forced to leave school because their parents could not afford the tuition, are all factors of relative and absolute impoverishment that drastically reduce the resources for achieving community redistribution. As victims of plummeting prices all over the world, the farmers (coffee and cacao planters, cotton growers and peanut farmers), far from being able to help their relatives in the cities, are also becoming ever poorer and appeal to them for help in increasing measure. When all is said and done, however, these city dwellers have either maintained their position or in a minority of cases managed to succeed in the system.

Basically, a serious question arises, amid this correlative blockage of the clientelist and community redistribution, regarding this underlying debt logic. Little wonder in these circumstances that African societies are permeated by a drive toward individualization (existential itineraries and subjectivities) that suggests rising individualism. ${ }^{34}$

This progressive individualization (privatization of practices, strategies and aspirations, growing independence, a devil-may-care view of community establishments, a major struggle to survive and to protect or promote personal interests to the detriment of solidarity) marks the four main fields of everyday life.

\section{Against impoverishment: the every-man-for-himself strategies}

This individualization appears first of all in the economy. As they say in Ivory Coast, "these days everybody is out for himself", and "everybody has

précarisé; final report, GIDIS-CI, ORSTOM, Centre ORSTOM de Petit Bassam, Abidjan, December 1994; Marie, "Y a pas l'argent", idem, L'Afrique des individus; idem, "La ruse de l'histoire. Comment, au nom du libéralisme, l'ajustement structurel accouche l'Afrique de ses classes sociales", in M. Haubert et al. (eds), Les sociétés civiles face au marché. Le chargement social dans le monde post-colonial (Paris, 2000, forthcoming).

32. The clientele becomes poorer, the deadbeats increase, as competition rises as laid-off workers and jobless graduates join the ranks of the self-employed.

33. Dismissals after rehiring workers formerly paid monthly with part-time contracts or as day labourers, thus alternating periods of uncertain and poorly paid employment with periods of forced inactivity.

34. See Marie, L'Afrique des individus. 
his own thing" (aujourd'bui chacun se cherche and chacun est dans son chacun). These adages reveal a prevailing quest for remunerative activity that makes the most of all opportunities, with virtually no regard for community support or corresponding obligations.

In Bamako, the modernist neo-entrepreneurs (unemployed graduates or skilled workers who have lost their jobs) thus affirm their will as self-made men by refusing to take out family loans which they would have to repay. ${ }^{35}$ As owners of popular restaurants in Abidjan, they try to disassociate their business from their family environment. ${ }^{36}$ Some avoid hiring relatives (they are difficult to dismiss, refuse wage advances to or absences for family events; demanding that they show up for work on time and are productive is another problem). Even if they dodge their financial obligations entirely, they do as little as possible (Bamako entrepreneurs indulge in salaries that secure the company's income and their personal income; they allocate a share for inevitable social spending from their personal income only).

In Mali young unemployed graduates understand that they are responsible for their fates. ${ }^{37}$ Aware of the limits of family solidarity (the system barely guarantees basic food and housing needs and is not equipped to resolve employment problems) in addition to the constraints it entails, they prefer to solve their problems themselves (s'en sortir) or enlist aid anonymously from institutions or even lobby through corporate organizations to impose their claims on the state (adjustment of hiring quotas for public offices, unemployment benefits, free transport and healthcare etc.).

More generally, many others get by with individual income improvised through haphazard opportunities, encounters and the ability to take advantage of anything that comes their way. In Abidjan, former employees brave the shame of loss of professional and social status associated with informal activities previously left to immigrants: ${ }^{38}$ a former accountant starts a small residential cleaning business; a former driver for a transport firm becomes a diallo (as the Nigerian owners of coffee houses are known); a former bank employee travels inland to buy up local products and resell them back home in the hope of opening a small shop one day; a worker laid off from an industrial company uses his compensation benefits to buy a used car and becomes the driver of a woro-woro (a small, cheap city taxi). Young adults without credentials form associations to collect household rubbish from neighbourhood enclaves, while others who have diplomas but lack job

35. R. Vuarin, "Les entreprises de l'individu au Mali. Des chefs d'entreprise innovateurs dans le procès d'individualisation", in Marie, L'Afrique des individus, pp. 171-200.

36. F. Leimdorfer, "Individus entre familles et entreprises : patrons et patronnes de restaurants populaires à Abidjan", in Marie, L'Afrique des individus, pp. II3-169.

37. E. Gérard, "La lettre et l'individu : marginalisation et recherche d'intégration des 'jeunes Diplômés' bamakois au chômage”, in Marie, L'Afrique des individus, pp. 203-248.

38. G. Kponhassia, "Reconversions professionelles, reconversions mentales. L'irruption des salariés ivoiriens au chômage dans le secteur des activités informelles autrefois abandonnées aux étrangers”, in Leimdorfer and Marie, Individualisations citadines, pp. 149-158. 
opportunities set up small companies offering computer services, for example. ${ }^{39}$

The precarious existence of these companies (which face intense competition, low profitability and thousands of annoyances arising from the predatory actions of a corrupt government), the fact that they were established through encounters between classmates or people sharing the same problems rather than family proximity, as well as their obligation to meet standards of economic profitability and to comply with legal regulations, all give rise to a certain distance from community solidarity obligations. Unable to afford the ostentatious ceremonial expenses or the demands for gifts associated with family visits, they return to their villages less frequently, concentrate their ability to help on their close relatives and, even if they do not abandon the solidarity ethic entirely, they postpone any such practices ("solidarity obligations are for the rich"). More generally, the lack of confidence in modalities of social integration, whether traditional (community solidarity) or modern (sociopolitical clientelism), paves the way toward personal efforts and an individualism with little concern for means ("nobody cares how you made your money: what matters is that you have enough to eat ${ }^{p}$ ) in an unbridled quest for money, as an omnipresent divinity amid scarcity, inequality, competition and heightened materialism ("in Ivory Coast, if you have no money you are nobody in your own eyes and in the eyes of the members of your family you are nothing").

\section{Against the debt logic: strategies of selective solidarity}

This individualization coincides with subjective questioning of the debt logic that is objectively compromised by impoverishment. Debtors are therefore hardly able to repay their debts or do so very scantily and selectively; no longer can they initiate a new cycle by doing others favours to benefit from their ulterior solidarity. Creditors note bitterly that those whom they had helped in the past still lack the means to honour their debts. ${ }^{40}$ This knowledge is all the more painful when creditors, who are themselves déflatés or compressés or suffer the more general effects of poverty, are in great need.

Thus, following the complaints by young people (they vary in age from fifteen or younger to twenty-five or older) who left school early because their fathers lacked money, but were nevertheless accused of not doing all the necessary favours for their children ("my father did not help me continue my studies"), the parents respond with recriminations against the

39. B. Ori, "Initiatives d'insertion socio-économique et démarches d'individualisation chez les jeunes citains d'Abidjan", in Leimdorfer and Marie, Individualisations citadines, pp. 159-178.

40. Such help may have included support during their studies, help with finding a job, funds to get them started, gifts of money, accommodation etc. 
laziness of these good-for-nothings. Many young city dwellers, tired of being insulted for their ongoing dependence, throw themselves into street life: they work as shoeshine boys, scarf or newspaper salesmen, car valets, windscreen washers, vendors of assorted trinkets for a larger merchant, guards for political parties, bodyguards or petty thieves, and sometimes dabble in drugs or organized crime. ${ }^{4}$ Young girls often join the ranks of the freshnies and the quinzanies, ${ }^{42}$ cashing in their freshness and their fifteen years for a few dozen francs quickly spent.

In turn, those who formerly held permanent jobs regret the social investments to which they devoted much of their resources when they were relatively prosperous. They find, at their own expense, that this money was wasted. The former company mechanic, after being laid off following a cutback in staff, lives frugally from occasional car repairs and has had to move into very small accommodation he shares with a girlfriend who has suffered similar misfortune and is unable to contribute anything to support the four children he had with former girlfriends during better times. $\mathrm{He}$ broods over having given far too much to others, especially to relatives who, compounding their ingratitude and deepening the shame he feels, now even ignore his existence: "They do not even know where I live. They never come see me!"

A former stockboy, a father of three forced to entrust his children to relatives who owed him favours from the past (a younger brother and a cousin), also notes the failure of the community solidarity network and the reciprocity principle according to which "a good deed is never in vain": not only do his former social investments bring him nothing today (except for caring for his children, albeit with many strings attached), but they have also prevented him from making other economic investments that would enable him to have his own small business ("I had fifteen people asking me for favours when I was working: solidarity prevents investments!).

A former technician at a refinery has difficulty coping with the transition from a privileged situation (a good salary and benefits derived through all kinds of fraud in the company's upper echelons) to being unemployed and in need. His predicament is all the more humiliating, because he is staying with an older brother who does not want him and refuses to help him start a small business. The technician emphasizes the ingratitude of those he helped in the past, especially his relatives with connections who, now that he needs them, disappear from him so that he is ashamed of contacting them and prefers to avoid them.

All these individuals question the debt logic. More specifically, without

4I. Alain Marie, "L'insécurité urbaine: l'engrenage des violences", in G. Hérault (ed.), Jeunes, culture de la rue et violence urbaine en Afrique, Proceedings from the international symposium in Abidjan, 5-7 May 1997 (Ibadan, 1997).

42. Ouattara, S., "Freshnies et quinzanies: la prostitution juvénile au secours des familles", in Marie, Paradoxes de lindividualisation, pp. 269-309. 
disputing the solidarity ethic that is the rose-coloured version, explicitly valorized and, as such, internally established, they learn with disappointment about its instrumental, utilitarian version. This is the one that now emerges as the naked truth.

The former mechanic, dreaming of opening "a modern garage of his own", but "currently unable to for lack of money", and the impossibility of enlisting any aid from this family to which he had "given far too much", learned that this community solidarity had failed, and that he had been swindled. He and his wife started to economize and began to live frugally, eating only one meal a day so that they would some day open the garage of his dreams. To this end, as the couple had to join forces to take distance from both his own parents and his in-laws, he formed a close partnership with his wife, who thus became an equal partner in the undertaking ("my wife has joined my project"). He said that he no longer let relatives live with him ("I will not let anybody stay with me anymore"). Without denouncing the solidarity ethic, if he succeeded, he would prefer to help individuals who were trustworthy rather than anybody taking advantage of being a relative. He now asserts that "it is better to help one's friends than one's family", thus expressing his preference for a limited, contractual solidarity, governed by an explicit rational principle of conditionality (based on deferred generosity), to the traditional, unconditional, imperative and massive solidarity (any individual from the same community is fully entitled to this solidarity, regardless of his relationship to the person from whom he is requesting aid).

Likewise, the former stockboy emphasized that he would dedicate his energies exclusively to his immediate family ${ }^{43}$ (his procreative family), and would no longer practise solidarity with the extended family of his origins, except as a strategic measure: selective, rational and conditional help, especially to assist those who had provided him with significant and tangible aid (in practice, close relatives or people who had acted as such), as well as those considered "likely to succeed" and thus able to repay their debt some day. Mainly, however, he devotes all his efforts to his conjugal family, and with the support and approval of his wife, who had become a full partner here as well, (his business was decisive for the household's survival): "Now I want to fight for my children and my own family. My wife helps me in my struggle."

The former technician has adopted the same view. He notes with pride that in his new solitude only his "little woman" with whom he cohabits "helps him with his small business". He therefore "listens to her advice", as, ultimately, "she is the only one on whom he can rely". He, too, has learned an important lesson from his own disappointment with community solidarity: the time of the "policy" of generosity (investing in favours to others)

43. They have no word for the conjugal family. 
is over. All he thinks about now is to "establish himself for his children". If one day he realizes his ambition of becoming a transporter, "he will no longer help others". Now, he "votes for himself". "Everything is for the wife and children, for the [conjugal] family". He will continue to see his true friends but will no longer give anything whatsoever to his original family. ${ }^{44}$ In the meantime, he will ask only his true friends - former colleagues who still hold their jobs - for small amounts of money and perhaps for leads that might help him find a job again.

Thus, against the logic of the community debt, the infinite debt (it is interminable, as it is never repaid in full), the indefinite debt (neither its amount nor its terms nor the recipients are predefined), and finally the unconditional debt (based on a true culture of altruism and constituting a categorical imperative for need imposed by the terrorist arsenal of witchcraft), and the dysfunctional aspects of the community solidarity network in a context of impoverishment and scarcity imposing an individualism of need required by the struggle for survival, African city dwellers aim to promote a radical revision of the actual principle without a dramatic break with the system. Without questioning solidarity as a value, they affirm their individuality in this respect and use their abilities to analyse and criticize, to redefine, each in his own way and according to his means, its conception and style of implementation. Henceforth, they all perceive the debt as somewhat relative and conditional (based on a rationale of generosity in that those who have given help will receive it), a limited and selective debt (they criticize ostentatious spending at large ceremonial gatherings; they distinguish between true creditors and others; they value supporting close relatives - father and mother, brothers and sisters "of the same father and the same mother"; they reject the idea of a debt toward more distant categories of relatives and especially toward the community in general; they affirm that they will indeed continue, if possible, to help a given individual but on the condition that his personal right to aid is recognized), and finally a strategic debt (the recipient of the aid is judged according to his specific aptitude to provide tangible and effective help in the long run).

The categorical imperative that is embedded intrinsically in hierarchical holism is replaced by the rational strategy principle and contractual negotiation between individuals able to impose their personal interests.

\section{Against witchcraft: strategies of religious protection}

Nevertheless, this community weapon, so perfect for calling to order individualists violating the debt law, is useful for accomplishing this

44. On the evolution of views regarding conjugality and the procreative family, see Alain Marie, "Les structures familiales à l'épreuve de l'individualisation citadine", in M. Pilon et al. (eds), Ménages et familles en Afrique. Approches des dynamiques contemporaines, Les études du Ceped, is (Paris, 1997), pp. 279-299. 
renegotiation and for seeking protection from the dangers of witchcraft. Rather than fading, witchcraft is more pronounced than ever in urban environments: countless educational or professional failures, individual redundancies, and sudden illnesses are blamed on witchcraft. ${ }^{45}$

The former stockboy who henceforth expects to "wage a personal struggle for his children and for his family" has become a zealous member of an evangelical church: "In Christ's hands, I do not fear witchcraft". And he has a compelling formula: "Now, I am no longer guided by the dead, as I belong to Jesus". Does this statement not reflect, in fact, this subjective reservation, this disengagement of a subject (in philosophical respects) thanks to mediation by an extracommunity and universalist religion, to the heteronomy of community roots and the retrospective temporality (that aptly captures the legal adage according to which "the dead seize the living") of the principle of linear solidarity, which, on the contrary, still subordinates the period of personal and individual projects to the cyclical and retrospective period of the debt toward one's elders and community of origin?

Increasingly, city dwellers are joining extracommunity religions (prophetic therapeutic and anti-witchcraft movements, ${ }^{46}$ Islamic associations, prayer groups, sects inspired by Oriental values, freemasons, Evangelical and Pentecostal churches), where they learn to disassociate from certain traditions: ${ }^{47}$ while we find a microsocial refuge and forms of mutual aid in hard times, we also observe a more personal approach in the search for meaning and new models of sociality that come between community solidarity (which is all the more threatening when defective) and the indifference of global society. These new communities are based on individual membership, where people experience new, more egalitarian fraternities (they are "brothers and sisters through Christ"), purged of the tensions inherent in family and village life, where an ethic of asceticism prevails, adapted to the existing personal hardship. They are also places where people seek effective protection from the witchcraft that is so threatening, in these times of individualization and questioning of the established order, that feelings of guilt arise, despite the assorted compromises reached with the debt regime.

One of the main reasons for joining these extracommunity religious movements is the desire to escape the contradictions of community solidarity, and to satisfy aspirations for individual autonomy, which are even greater than the dysfunctioning of the debt system would suggest. The

45. See Alain Marie, "Avatars de la dette communautaires. Crise des solidarités, sorcellerie et procès d'individualisation (itinéraires abidjanais)", in Marie, L'Afrique des individus, pp. 249-328. 46. On this subject, see Colette Piault (ed.), Prophétisme et thérapeutique (Paris, I975); Jean-Pierre Dozon, La cause des prophètes. Politique et religion en Afrique contemporaine (Paris, 1995), for case studies of Ivory Coast.

47. For a case study of the role of these Pentecostal religions in Ghana, see Birgit Meyer, "Les églises pentecôtistes africaines, Satan et la dissociation de la 'tradition'", Anthropologie et sociètés, 22 (1998), pp. 63-84. 
extra-community religious circle (more generally, the spiritual renewal movements), by promoting new types of social links based on a fraternity mediated by a central institution prohibiting ambivalence toward others, form a social sphere from which individuals, still imbued with a religious perception of the world that excludes agnosticism, derive support.

\section{Against the hierarchical principle: the strategy of political commitment}

There is still another sphere, however, where the same individuals question their submission to their community that they previously took for granted and come up with opposing ideas. In politics, through recognizing the arguments of their own revolts and their previously rather diffuse aspirations in the analyses drafted by the opposition parties, as well as on international radio stations, they learn new words to identify their existential problems, thereby giving them a different, objective and secularized meaning. ${ }^{48}$ Along with their attribution of individual misfortune to witchcraft, they appropriate other general explanatory principles: the predatory state, the oligarchy's exclusive concern with individual enrichment and power retention, the failure of authoritarian development modes, the corruption of politicoadministrative elites, embezzlement, nepotism, clan favouritism. With the impact of globalization and the anticorruption conditions imposed these days by international moneylenders, modern society becomes a generator of exclusion. In this society, clientelism, as an instrument of the state's legitimation and reproduction of the consent by those dominated to their domination without appeal, no longer serves in this capacity as it did in the past. ${ }^{49}$ This trend signifies a new, political conception of solidarity now being adopted by city dwellers: as fully individualized political subjects, citizens can impose the macrosocial solidarity that the conjunction of social justice and political liberty provides in a democracy, once democratic settlement of political conflicts and sanctioning of those with political power through free and transparent elections become possible.

Thus, referring sometimes to their recent militant involvement (since 1990, upon the rise of the multiparty system) in new opposition parties or autonomous syndicates (i.e. independent of the Union Générale des Travailleurs de Côte d'Ivoire, enfiefed in the former single party in power), the citizens of Abidjan are now very able to invoke all aspects of this universal

48. See Alain Marie, "Pas de société civile sans démocratie. Contre l'État et sa société, l'exigence démocratique des jeunes chômeurs abidjanais engagés dans l'opposition", in Leimdorfer and Marie, Individualisations citadines, pp. 63-III, "La ruse de l'histoire".

49. This crisis of the sociopolitical debt is highlighted, for example, in the following statement: "Among our ministers, there are many to whom we have given money [often the entire extended family, including all the heads of a village family, contributed toward their study costs]. And they do not help. There has been a break in contact." 
causality that attributes meaning to their misfortunes, their revolts, and their aspirations. For example:

Ivory Coast is wealthy [...]. Unemployment among young adults is wrong [...]. Too many injustices exist in this country [...]. In France, they have a minimum wage. Here, they have nothing.

They have taken all the money. They are the ones who eat. Not the rest of us.

Unemployment, hooligans, bandits are all the outcome of the course of events, failure in school, lack of skills [...]. All this mismanagement has arisen from lack of criticism or opposing debate.

Establishing a link between political authoritarianism and community authoritarianism and denouncing the culture of submission long maintained by these two accessory orders is becoming a widespread preoccupation among young city dwellers. On this topic, the following statements are significant:

We, the children of this country, lacked the right to express ourselves [...]. We paid for our PDCI [the former single party] membership cards, which we called "taxes" [...]. The village chief ordered us to purchase the cards.

Our elders are exhausting us and exploiting us.

Our leaders are responsible. But, according to an African adage "when you are an earthworm, do not complain if they step on you" [...]. We Africans bear primary responsibility. We need to change our attitude.

A democracy offers freedom of association, religion, and opinion.

\section{CONCLUSION}

Individualization of itineraries and awareness of oneself and others does not culminate in postmodern individualism (the self-inverting kind), which entails valorization of individual independence and dissolution of assigned sociality bonds. Individualism remains impossible amid a crisis in which an organized and accessible system of social protection is lacking. Resorting to community solidarity continues to be a form of security and insertion in contemporary society (access to school, employment, and the city). Nevertheless, individualization is apparent in the analyses and criticism of the community solidarity logic (that of an individual's debt to the community), called into question by the emergence of a major contradiction. On the one hand, the economic crisis, by rendering solidarity increasingly necessary, makes the system more akin to an anti-individualist categorical imperative (eroding solidarity's traditional self-evidence, the crisis turns it into an explicit, urgent necessity and places it in a context of suspicion and resentment expressed in the witchcraft idiom). On the other hand, as the available resources dwindle while costs rise, the economic crisis leads to severe dysfunctions in the system's reproduction and legitimation: the process of individuals incurring debts - especially while they are in school and are 
embarking on their professional careers - is often unfinished, unsatisfying, and riddled with failures and disappointments. The debtors, who remain or become insolvent, are bitter toward parents that they consider inadequate or malicious, while fearing their rancour for having made unproductive investments. On the other hand, the creditors feel they have been cheated and dwell on their disappointment at not being repaid by their "children", or that these "children" have "succeeded" but are "ungrateful".

In this context of constraints, as well as the feasible and conceivable opportunities arising from this contradiction, critical (reformatory) awarenesses emerge that herald the individual's rise as a subject inclined toward autonomous ideas and actions. This process becomes apparent along the social and cognitive trajectories that are determined both by objective conditions of existence and by strategic intent: recourse to achieved forms of sociality with the valorization of elective social investments and the selective and contractual recomposition of relations with the community social surroundings; questioning the unconditional and massive debt for the benefit of a social, conditional, negotiated, and reasonable debt; the quest for personal new identities and new forms of sociality (reconstruction of collective identities), through diversified religious itineraries and syndicated and political commitments as well. All these processes coincide with the advent of a civil society, a "society of individuals" (Elias), henceforth individualized as subjects increasingly affirm their own needs and demands as much against community despotism as against postcolonial state despotism.

Translated by Lee Mitzman 